DOI https://doi.org/10.36059/978-966-397-212-1/31-56

\title{
PART 2. \\ CARPATHIAN UKRAINE IN THE INTERNATIONAL RELATIONS: FROM THE MUNICH CONFERENCE TO THE VIENNA ARBITRATION
}

In the late 1930s, a severe international crisis arose in Central Europe. Nazi Germany and Italy were preparing for a new division of the world. The danger of World War II loomed over Europe. Czechoslovakia, which included Transcarpathia under the name of Subcarpathian Rus', was in a difficult situation. From the second half of the 1930s, there was an accelerated process of militarization of Hungary. This country bordering on Transcarpathia constantly put forward aggressive plans for the region. Consequently, due to sociopolitical circumstances, Transcarpathia, which was located in the centre of Europe, was invariably part of the interests of different states $^{89}$.

89 Богів О. Вплив карпатоукраїнського (підкарпатського) фактора на зовнішню політику Радянського Союзу в період чехословацької кризи 1938-1939 років. Украӥнські землі в роки Другої світової війни: Науково-методичний збірник матеріалів конференції. 19 грудня 1997 р. Ужгород, 1998. С. 29-41; Богів О. Карпатська Україна (Підкарпатська Русь) і політика європейських держав в радянській історіографії (1944-1991 рр.). Закарпатська Україна: 1945 рік: Матеріали наукової конференції, присвяченої 50-річчю Перемоги над фашизмом та 50-річчю возз'єднання Закарпаття з Україною. 26 травня 1995 р. Ужгород: Патент, 1995. С. 78-91; Богів О. Карпатська Україна і політика країн Центральної Свропи (березень-листопад 1938 р.). Актуальні питання історії Закарпаття. Ужгород, 1992. С. 4-9; Богів О. Карпатська Україна і політика країн Центральної Свропи (березень-листопад 1938 р.). Збірник наукових студентських робіт: Актуальні питання історії Закарпаття. Ужгород, 1992. Вип. 1. С. 9-14.

Богів О., Вегеш М. Міжнародне становище Карпатської України (1938-1939 рр.) / Ужгородський державний університет. Ужгород, 1997. 136 с.; Богів О., Вегеш М., Задорожний В. Галичина і Карпатська Україна у 1938-1939 роках. Украӥна. Культурна спадщина. Наџіональна свідомість. Державність: Збірник на пошану професора Юрія Сливки / Національна Академія Наук України, Інститут Українознавства ім. І. Крип'якевича. Львів, 2000. Вип.7. С. 428-444; Богів О., Задорожний В. Карпатська Україна (Підкарпатська Русь) у міжнародних відносинах (травень 1938 р. - березень 1939 р.). Ужгород, 
On September 29-30, 1938 a conference was held in Munich with the participation of Germany, Italy, France and the United Kingdom, surpassing in its shamelessness everything that took place after the First World War. The fate of the Czechoslovak Republic was decided during this conference, though the representatives of this country were not allowed to attend the conference. It should be noted that the idea of liquidation of Czechoslovakia has been prepared for a long time. Former US Consul in Berlin H. Messersmith told at the Nuremberg Trial: "As I learned from my diplomatic colleagues, von Papen in Vienna and his colleague von Mackensen in Budapest had openly promoted the ideas of full dissection and ultimate accession of Czechoslovakia..." ${ }^{90}$. This was confirmed in a letter of a Hungarian Ambassador in Germany, D. Stoai, to the Minister of Foreign Affairs, K. Kanya, dated August 1, 1936: "We need to focus all our efforts on Czechoslovakia. Hitler acknowledges that our goals are the same in relation to Czechoslovakia, but he plans to implement them at a later time. He hates the Czechs"91. The Prime Minister of Prussia, H. Goering, during a conversation with K. Kanya, on October 11, 1936, stated unequivocally that "Germany will in no way change its plans for Czechoslovakia" "92.

Chief of "Abwehr-1", Hans Piekenbrock, wrote in his diary: "When I was appointed to the Ausland/Abwehr Department at the Ministry of defence in 1936, the tasks facing Abwehr-1 were next: 1. Organization of major intelligence operations in such countries: France, Czechoslovakia, Poland, England, Russia, Spain (Civil War). 2. Organization of secondary intelligence operations in the countries: Belgium, Switzerland, Yugoslavia, Romania, USA. 3. Countries, where it is forbidden to conduct intelligence operations: Austria,

1999. 91 с.; Василина Н. Карпатська Україна в міжнародних відносинах напередодні Другої світової війни. Нове бачення подій. Ужгород: Всеукраїнське державне видавництво «Карпати», 2008. 224 с.; Вегеш М., Віднянський С. Країни Центрально-Східної Європи та українське питання (1918-1939) / Національна Академія Наук України, Інститут історії України, Ужгородський державний університет. Київ - Ужгород, 1998. 257 с.

${ }^{90}$ Венгрия и вторая мировая война: Секретные дипломатические документы по истории кануна и периода войны. М.: Наука, 1962. С. 48.

${ }^{91}$ Ibid. C. 52.

92 Ibid. C. 53. 
Italy, Hungary, Finland, Estonia, Japan, Bulgaria. 4. All other countries did not cause interest and intelligence operations were not conducted on their territory. At that time, the Wehrmacht was in the initial stages of formation, so the main target of intelligence were the armies of neighbouring countries - Poland and Czechoslovakia... The increasing number and orientation of the tasks clearly indicated Hitler's intentions and the OKW to occupy the Czech Republic. The intelligence operations were successful in general, as we succeeded in recruiting in the border area a large group of agents among the Sudeten Germans and conscripts of the Volksdeutsch (ethnic Germans) into the Czech army. In order to enhance intelligence operations in the Czech Republic, there were additionally established Abwehr offices in Vienna and Nuremberg. The "Abwehr-1" office in Vienna was staffed with a selected contingent, since strong family ties between the Sudeten Germans, Austrians and Czechs provided ample opportunities for the Abwehr sabotage operations in the region...."93.

The views of German leaders were fully supported by Italian Minister of Foreign Affairs G. Ciano: "Italy does not seek any agreement with Prague, although there are no direct contradictions between the two countries. In a word, Rome fully shares Germany's position on Prague"94. During Hitler's visit to Italy on the eve of the Munich Conference, the Czechoslovak problem was discussed only once, and quite superficially. But it was known that Mussolini spoke about Czechoslovakia with humiliation. As if preparing the country for the implementation of German plans, Duce emphasized in his speeches the need to consider and resolve the Czechoslovak question. Mussolini stated in one of these speeches: "If Czechoslovakia finds itself today in a situation that it itself could define as delicate, it is only because it was - you could say, it was, already - not just Czechoslovakia, but Czech-German-Polish-Hungarian-CarpathianUkrainian-Slovakia" ${ }^{95}$. It should be noted that Mussolini did not want

\footnotetext{
93 Мадер Ю. Абвер: щит и меч Третьего Рейха. Ростов-на-Дону: «Феникс», 1999. С. 59-61.

94 Венгрия и вторая мировая война: Секретные дипломатические документы по истории кануна и периода войны. М.: Наука, 1962. С. 59.

95 Хибберт К. Бенито Муссолини. Ростов-на-Дону: «Феникс», 1998. С. 149.
} 
to involve Italy in a war for which it was not ready. He was well suited to the position of a mediator in solving the Czechoslovak question. He admitted this in a conversation with G. Ciano. Mussolini ordered his ambassador in Berlin Attolico to go to Hitler immediately to assure the Fuhrer that Italy remains on Germany's side, proposing, however, to postpone military mobilization for twenty-four hours ${ }^{96}$.

The leaders of the Third Reich, being well aware of Hungary's aspirations to regain their "eternal territories", constantly pushed Budapest to take active action against Czechoslovakia ${ }^{97}$. Hitler also advised Hungary "not to dissipate its political strength in different directions, but to point it to one side, namely towards Czechoslovakia"98. Although the emphases in Germany's foreign policy will change over time, this will not affect the direction of the fascist general line regarding Czechoslovakia. On May 30, 1938 Hitler issued a directive on the preparation for war action against Czechoslovakia. The plan of attack was codenamed "Grun". According to it, "Czechoslovakia must be crushed in the near future as a result of war actions... All preparations must be carried out immediately... In the first 2-3 days there can be created a situation that will show... all the futility of the Czech military situation, and for those states that have territorial claims on Czechoslovakia, it will be an incentive to attack it immediately. In this case, we should expect Poland and Hungary to act" $" 99$.

However, it should be noted that not all the high officials of the Third Reich shared Hitler's views. The most radical anti-Hitler position was occupied by Franz Halder, who, since September 1, 1938, replaced Ludwig Beck as Chief of the General Staff of the Army High Command. He, along with Secretary of State Waizsacker, negotiated with British politicians to counter Hitler's plans for Czechoslovakia. However, N. Chamberlain could not comprehend how F. Halder wants to enlist the support of Great Britain, contrary to

\footnotetext{
${ }^{96}$ Ibid. C. 150.

${ }^{97}$ Венгрия и вторая мировая война: Секретные дипломатические документы по истории кануна и периода войны. М.: Наука, 1962. С. 64.

${ }^{98}$ Ibid. C. 67.

${ }^{99}$ Ibid. C. 97.
} 
the political goals and intentions of his own leadership ${ }^{100}$. Abwehr chief Wilhelm Canaris also belonged to those people who were clearly aware that a violent solution of the German question in the Sudeten would lead to war in Europe. He tried to do his best to avert this danger from Germany and Europe. It is known, for example, that W. Canaris contributed to a relatively moderate direction among the Sudeten Germans, led by Henlein, as opposed to the extremist national-socialist wing, led by Karl Hermann Frank ${ }^{101}$.

W. Canaris, having had long-standing contacts with the relevant services of Hungary and Italy, tried to convince them of the need for a peaceful solution of the Sudeten question. By the way, there was cooperation between Abwehr and Hungarian intelligence, which included surveillance of Czechoslovakia, Eastern and South-eastern Europe. Personal ties of Canaris in Hungary soon transcended from the military sphere into the political. Minister of Foreign Affairs K. Kanya also belonged to the people with whom Canaris had a trusting relationship. On the eve of the Sudeten crisis in the fall of 1938, Canaris together with Colonel of the General Staff Tippelskirch, visited Budapest to warn Hungary of participating in the so-called "broad solution" of the Czechoslovak question, that is, the elimination of Czechoslovakia by force of arms. Canaris did similar work in Italy, but his initiative did not bring significant success ${ }^{102}$. W. Canaris was well aware that the situation depended most on Britain, and was, therefore, disappointed by N. Chamberlain's compliant position. The influential official of the German Ministry of the Interior Affairs and later the German Vice-Consul in Zurich, Hans

\footnotetext{
100 Стерчо П. Національне відродження Карпатської України. Організація Украӥнських Націоналістів. 1929-1954. Мюнхен, 1955. С.188-210; Стерчо П. Роля Карпатської України в зактуалізації всеукраїнського питання в міжнародній політиці 1938-1939 рр. Сучасність. 1965. Т. 11. № 7. С. 4-8; № 8. С. 8-10; № 9. С. 19-20; Стерчо П. Словацько-українські взаємовідносини. 1938-1939. Сучасність. 1965. Т. 5. № 9. С. 85-101; Стерчо П. Урядова координація операцій мадярських і польських терористів у Карпатській Україні в 1938-1939 рр. Філядельфія, Па: Видавництво «Америка», 1971. 26 с.; Стерчо П. Урядова координація операцій мадярських і польських терористів у Карпатській Україні в 1938-1939 рр. Державність. 1993. № 1. С. 15-24.

${ }_{101}$ Штрассер О. Гитлер и я. Ростов-на-Дону: «Феникс», 1999. С. 176-177.

102 Ibid. C. 184-185.
} 
Bernd Gisevius, was also disappointed with Great Britain ${ }^{103}$. However, N. Chamberlain, twice visiting Hitler before the conference, actually contributed to the division of Czechoslovakia.

Consequently, not all high-ranking German officials shared Hitler's expansionist plans. It is likely that, knowing this, Hitler made a great deal of effort to bring the majority of the generals to his side. This is evidenced in E. Manstein's memoirs ${ }^{104}$. J. von Ribbentrop also believed that "the oppression of the German minority in Czechoslovakia was not at all a fiction of Adolf Hitler. It began in 1918. After the Nazis took power in 1933, it was undoubtedly intensified, and the cultural life of the Germans in Czechoslovakia was increasingly eroded"105. And in general, Ribbentrop stated: "The Czechoslovak people as such have never existed - either before or after 1918. On the contrary, it was a multinational state with various national groups, to which, besides the Czechs, belonged Germans, Hungarians, Poles, Ruthenians, Carpathian Ukrainians and Slovaks. The artificial formation, which was Czechoslovakia, created in 1919 from such heterogeneous elements, from its very inception moved to disintegration and could only be preserved as a result of strong Czech pressure" ${ }^{\text {106 }}$. The future English Prime Minister Winston Churchill sympathized with the Sudeten Germans, who numbered at about three million in Czechoslovakia. During a meeting with Conrad Henlein, W. Churchill supported his efforts for autonomy, but strongly opposed the transfer of the Sudeten to Germany ${ }^{107}$.

The ideological consideration for Hitler's aggressive plans was carried out by his propaganda minister, Joseph Goebbels ${ }^{108}$. However, Goebbels did not tell about one important detail: a few months before the sports holiday in Breslau Hitler had already decided to split Czechoslovakia. Historians E. Bramstedte, G. Frenkel and

\footnotetext{
103 Гизевиус Г.Б. До горького конца. Записки заговорщика. Смоленск: «Русич», 2002. С. 296-297.

${ }_{104}$ Манштейн Э. Из жизни солдата. Ростов-на-Дону: «Феникс», 2000. С. 281-282.

105 Риббентроп И. Тайная дипломатия III Рейха. Смоленск: «Русич», 1999. C. 146 .

${ }^{106}$ Ibid. C. 145-146.

${ }^{107}$ Роуз Н. Черчилль. Бурная жизнь. М.: АСТ, 2003. С. 206.

108 Брамштедте Е., Френкель Г., Манвелл Р. Йозеф Геббельс. Мефистофель усмехается из прошлого. Ростов-на-Дону: «Феникс», 2000. С. 232.
} 
R. Manwell have noted that, thanks to Goebbels, "Hitler was portrayed as a kind and wise statesman of European scale" ${ }^{\text {"109 }}$.

Thus, a plan to attack the Czechoslovak Republic began to be drawn up at the German General Staff long before the Munich conference. General Field Marshal Erich von Manstein recalled that in the summer of 1938 the OKH informed him that in the case of a conflict with Czechoslovakia, he would perform the duties of the Chief of Staff of the Army, which will be stationed at the BavarianCzechoslovak border ${ }^{110}$. H. Himmler together with Heidrich created a sabotage squadron of the SD, which had to follow the German army in order to "ensure the security of political life and the national economy". Four days before the Munich Agreement, when the invasion in Czechoslovakia seemed already resolved, H. Himmler informed Henlein that he and his militia corps would be subordinated to him personally. At the same time, six battalions of security from the "Dead Head" units were brought to the border without the sanction of the high command, which overturned his orders to Henlein and gave instructions that the SS soldiers should be controlled by the military men. The order ended with an indication that all "further measures should be agreed between the commanderin-chief of the army and the Reichsführer of the SS"111.

Hitler tried to hide his ultimate goal against Czechoslovakia, saying that he wanted only to release the Sudeten Germans, who were allegedly discriminated in the Czechoslovak Republic. To stop this, he demanded that Great Britain and France should "press" on Czechoslovakia. President of Czechoslovakia E. Benesh was in a difficult position. On the one hand, Britain and France insisted on the mandatory adoption of an ultimatum, and on the other, his own people demanded that he should rely on the treaty-allies ${ }^{112}$. At the same time, Earl E. Halifax was convinced in another thing: "At present, no European combinations can prevent the suppression of

\footnotetext{
109 Ibid. C. 233.

${ }^{110}$ Манштейн Э. Из жизни солдата. Ростов-на-Дону: «Феникс», 2000. С. 279.

111 Брамштедте Е., Френкель Г., Манвелл Р. Йозеф Геббельс. Мефистофель усмехается из прошлого. Ростов-на-Дону: «Феникс», 2000. С. 108-109.

112 История внешней политики СССР. Т.1. 1917-1945 гг. М.: Наука, 1986. С. 334-339.
} 
Czechoslovakia"113. Of course, this was only said in a narrow circle. Czechoslovakia was further persuaded that the Sudetenland was the last to be claimed by Hitler.

The conference in Munich, according to Soviet Ambassador in the United Kingdom, I. Maysky, was held "at a machine-gun speed: it started at 1 p.m. and ended at 2 hours 45 minutes on September 30, including the time for breakfast, lunch and other necessary breaks. The fate of Czechoslovakia was resolved in less than 13 hours. And not only the fate of Czechoslovakia"114. Even Hermann Goering was surprised at the speed of the conference: "In reality, it all went quite simple. Neither Chamberlain nor Daladier were ultimately interested in sacrificing or risking anything to save Czechoslovakia. It was clear to me as day. Its fate was mostly resolved within three hours. Then three hours went into the dispute over the word "guarantee"115. This conference was the first stage of what Hitler spoke about on May 28, 1937, at an extraordinary meeting of all senior leaders of his empire: "My invariable decision is to wipe Czechoslovakia off the map" The results of the conference were announced to the representatives of the Czechoslovak Republic as a non-negotiable verdict.

The Munich Conference made a really brutal stroke to Czechoslovakia. The latter lost half of the heavy industry, $66 \%$ of coal, $70 \%$ of electricity, $70 \%$ of ferrous metallurgy, $86 \%$ of the chemical industry, $80 \%$ of the textile industry. In fact, "what remained of the crushed and split country was now at Hitler's feet",117. According to official statistics, "Czechoslovakia had 140.400 square kilometers and 15.3 million citizens. Germany took 28.200 sq. km.

\footnotetext{
113 Вони боронили Карпатську Україну: Нариси історії національно-визвольної боротьби закарпатських українців / М.М. Вегеш, М.В. Делеган, О.Д. Довганич та ін. [Відп. ред. М.М. Вегеш]. Ужгород: Карпати, 2002.

${ }_{114}$ Майский И.М. Воспоминания советского дипломата. М., 1987. С. 366.

115 Мирович М.О. Генерал де Голль: Штрихи к политическому портрету. Ростов-на-Дону: «Феникс», 2000. С. 55-56.

116 Вони боронили Карпатську Україну: Нариси історії національно-визвольної боротьби закарпатських українців / М.М. Вегеш, М.В. Делеган, О.Д. Довганич та ін. [Відп. ред. М.М. Вегеш]. Ужгород: Карпати, 2002.

117 Вегеш М., Задорожний В. Велич і трагедія Карпатської України: Історикопопулярний нарис. Ужгород, 1993. С. 12.
} 
and 3.6 million inhabitants"118. Not only did Czechoslovakia lose a fifth part of its territorial area and almost a fourth part of its population, but the fact that Prague was located $40 \mathrm{~km}$ from the German border was also threatening. The Munich Conference struck a heavy blow to Czechoslovakia's defence capability. By this act, Britain and France had lost a strong ally, for Czechoslovakia had 45 divisions, 1582 aircraft, 469 tanks, 5700 guns. The Germans understood this well, and when developing the "Grun" plan, they planned to send 39 divisions to Czechoslovakia. France forgot about its personal security, which in 1940 was skilfully used by Hitler, capturing it in a few days.

How was the Munich Conference treated in the ruling circles of the allies of Czechoslovakia? Realistically thinking English politician W. Churchill, mentioning the great miscalculations of his government, stated that "we (Britain - Aut.) have suffered a defeat without war, the consequences of which will be felt for a very long time. We have gone through a terrible phase in our history when Europe's equilibrium was broken... Don't think that it is the end. This is only the beginning of the reckoning. This is only the first sip, the first treat of this bittersweet cup that we will be offered year after year"119. Taking a speech in Weimar, Hitler pointed at his island enemy: "If Mr. Churchill had less to do with traitors and more with the Germans, he would have seen that he's taking an unthinkable affair, for I can assure this man, who seems to live on the moon, that Germany has no forces opposing the regime - only the forces of the National Socialist movement, its leaders and defenders" ${ }^{\text {"20 }}$. The Fuhrer warned that if Churchill will return to power then Germany will be facing a war.

The Parliament of Great Britain, with 366 votes to 114, approved the Munich Conference. Labour Party voted against it, 30 or 40 conservatives who disagreed with the government in Munich's assessment, including Churchill, abstained. The Czechoslovak crisis, according to German Ambassador to London H. Dirksen, was treated in Great Britain "rather as a natural disaster that went smoothly

\footnotetext{
118 Нова свобода. 1938. 2 листопада.

119 Трухановский В.Г. Уинстон Черчилль. М.: Мысль, 1989. С. 256.

${ }^{120}$ Уткин А. Уинстон Черчилль. М.: «Адгоритм» - Эксмо, 2002. С. 262.
} 
enough and for which no one was held responsible"121. "Munich was the most correct," the ambassador of Poland to London Raczynski described the mood of the English ruling circles, "if not the only way out of a desperate situation" $"$. Minister W. Elliott expressed similar views $^{123}$. In the French Chamber of Deputies of 600 parliamentarians only 75 condemned the Munich Conference. The fate of Czechoslovakia was of little concern to anyone ${ }^{124}$. However, French politicians did not fully believe that Hitler would adhere to the Munich Agreement. For greater certainty, at the end of September 1938, a couple of millions of gas masks were given to the population. Shortly afterwards, S. de Gaulle wrote to Paul Reynaud: "The events with striking clarity show your rightness... My regiment is ready for battle. As for me, I am not surprised with the coming of great events in the history of France...". On September 29, when the Munich conference has already begun, one officer asked him: "What to do now?" - and de Gaulle calmly said: "To fight"125.

US Ambassador to Paris W. Bullitt on September 27, 1938, that is, two days before the start of the conference, informed the Washington: "I think it's 95\% likely that the war will start on Friday night..." The war has not yet begun, however, the Munich Conference has not

\footnotetext{
121 Трухановский В.Г. Уинстон Черчилль. М.: Мысль, 1989. С. 257.

122 Документы и материалы кануна второй мировой войны. Т.1. Ноябрь 1937 декабрь 1938 г. Из архива Министерства Иностранных Дел Германии. М.: Политиздат, 1981. С. 86-87.

${ }^{123}$ Роуз Н. Черчилль. Бурная жизнь. М.: АСТ, 2003. С. 312.

124 Артюхина-Московченко В. Шарль де Голль и Советский Союз. М.: Книга, 1990. C. 76.

125 Ibid. C. 75.

${ }^{126}$ Вегеш М., Задорожний В. Велич і трагедія Карпатської України: Історикопопулярний нарис. Ужгород, 1993. С. 12; Баран О. Проблема Закарпатської автономії в Угорщині в 1939-41 pр. Закарпаття під Угорщиною. 1938-1944 / Упорядкування та передмова Василя Маркуся та Василя Худанича. Ужгород: Карпати - Гражда, 1999. С. 49-63; Баран О. Угорська влада на окупованому Закарпатті (1938-1944). За Украӥнське Закарпаття: Дослідження, статті, cnогади. Ужгород: Гражда, 1994. С.11-15; Баран О. Чехо-Словаччина і уряд Карпатської України. Карпатська Украӥна $і$ Августин Волошин. Матеріали міжнародної наукової конференції «Карпатська Україна - пролог відродження української держави». Ужгород: Гражда, 1995. С. 41-47.
} 
become a cold shower for the US administration ${ }^{127}$. From September 12 to September 30, the ninth studio of the CBS radio company made 85 broadcasts, in most cases directly from Europe. Millions and millions at the receivers were horrified by Hitler's hysterical speeches... They acutely felt their helplessness and fear... Conclusions: a poll by "Fortune" showed that only 11,6 percent believed the Munich agreement to be approving, 76,2 percent believed that USA will take part in the war in Europe (a year and a half ago - only 22 percent). The CBS was pleased to confirm the result: radio now not only spreads the news, but it also acts as a social force" ${ }^{\prime 28}$. US diplomat George Kennan expressed his opinion on the consequences of Munich ${ }^{129}$. In the deep conviction of G. Kennan, "Czechoslovakia is, after all, a Central European country and its fate, one way or another, is linked to the main forces, which are operating in the region" 130 . However, the Roosevelt administration began to increase its military potential. In January 1939, an additional assignation of half a billion dollars to the military department followed. In the following months, in the spring of 1939, the United States finally started to revise the Neutrality Act. In May, Secretary of State, Hell, expressed the government's intention to allow warring states to buy weapons from the US ${ }^{131}$.

In the case of annexation of Czechoslovakia by the Nazi Germany, a direct road to Poland was opened before the Third Reich, which could have become a bridgehead for the attack on the USSR. It was in the interests of Britain and France. It is clear that the Soviet Union could not allow this, understanding pretty well what a liquidation of Czechoslovakia could bring to it, and therefore did everything to help it. It is possible that this assistance was not sincere, but was an ordinary attempt to survive in extremely difficult international conditions. Ten days before the Munich Conference, E. Benesh

127 Яковлев Н.Н. Избранные произведения. М.: Международные отношения, 1988. C. 260.

128 Ibid. C. 260-261.

129 Кеннан Дж. Дипломатия Второй мировой войны глазами американского посла в СССР. М.: Центрполиграф, 2002. С. 66.

${ }^{130}$ Ibid. C. 67.

${ }^{131}$ Уткин А. Уинстон Черчилль. М.: «Адгоритм»- Эксмо, 2002. С. 74-75. 
addressed the USSR government with a letter, asking whether the USSR would fulfil its allied obligations. On September 20, the Soviet government gave a positive answer. If earlier the USSR had stated that it would assist Czechoslovakia only if France will do the same, now it has made concessions: "The USSR will provide military assistance to Czechoslovakia, even without the participation of France, and when Czechoslovakia will defend itself and will ask for its assistance"132. This was confirmed by the People's Deputy Commissioner for Foreign Affairs M. Litvinov in a conversation with the Soviet Ambassador to the United Kingdom I. Maysky: "The most important thing is how the Czechs will behave... If they will fight, then we will help them with an armed hand". On September 25, 1938 the USSR reported to Paris that, according to the treaty, the troops were ready to defend Czechoslovakia.

According to archival materials, the measures taken by the USSR to protect Czechoslovakia were large-scale: June 26, 1938 - the urgent formation of six army and one cavalry groups; September $23-$ bringing to combat readiness of one tank corps, 30 infantry and 12 aviation brigades. Then another 17 infantry divisions, three tank corps, 22 tank and three motorized infantry brigades, 34 aviation bases. In addition, the second echelon of troops, consisting of 30 infantry and 6 cavalry divisions, 2 tank corps, 15 separate tank brigades, 34 aviation bases were put on alert. A total of about 300,000 people were recruited to the armed forces. Directives were sent to the Kyiv, Kharkiv, Byelorussian, Moscow, Kalinin and Leningrad military districts ${ }^{133}$. There was nothing about Subcarpathian Rus' in the statements of the USSR government. They were about Czechoslovakia in general. However, protection of the integrity of Czechoslovakia was also a protection of the interests of Transcarpathia, which Hungary wanted to invade ${ }^{134}$. On September

\footnotetext{
132 Вегеш М., Задорожний В. Велич і трагедія Карпатської України: Історикопопулярний нарис. Ужгород, 1993. С. 9.

133 Артюхина-Московченко В. Шарль де Голль и Советский Союз. М.: Книга, 1990. С. 73.

134 Гранчак I.M., Гапоненко I.C. Закарпаття в міжнародних відносинах напередодні та в період Мюнхена. Нариси історії Закарпаття. Т.II. (19181945).Ужгород, 1995. С. 267.
} 
23, 1938 the USSR government informed Warsaw that if Polish troops crossed the Czechoslovak border, the Soviet Union would consider the Soviet-Polish treaty of July 25,1932 to be terminated ${ }^{135}$. In Poland the statement of the USSR was treated as a direct support of Czechoslovakia. The Soviet Union strongly condemned the decision of the Munich conference.

We must agree with L. Bezimensky's view that the USSR has suffered most from the consequences of Munich. It delivered a "major blow to its international prestige. Again, the country was pushed to the outskirts of world politics. The mechanism of military cooperation with the West was also not used. The USSR lost a good partner - Czechoslovakia"136. However, Munich forced the USSR to radically change the orientation of its foreign policy, which subsequently led to the conclusion of infamous treaties between Stalin and Hitler in 1939. Such a course of events was predicted by the adviser to the German Embassy in Moscow Werner von Tippelskirch: "It seems to us that Stalin will make personal conclusions about the failure of the Soviet politics... If we go to the field of political speculation, it seems that the Soviet government should reconsider its policy. First of all, it concerns relations with Germany, France and Japan. What about us, the more positive attitude of the Soviet Union towards Germany could be possible, at least because France is devalued as an ally and Japan takes an aggressive stance... Anyway, I do not consider it absurd that the present circumstances create favorable opportunities for a new, larger-scale economic agreement with the Soviet Union" ${ }^{\text {137. }}$ Undoubtedly, he was not mistaken.

The leadership of Czechoslovakia was well aware of the tragedy of its situation. When handing over Munich's demands by the German attorney in Prague, A. Henke, the Czechoslovak Minister of Foreign Affairs K. Krofta said that for Czechoslovakia "this is a disaster, which we did not deserve. We obey and will try to provide a peaceful life for our people. I do not know if your countries will

135 Документы и материалы по истории советско-чехословацких отношений. Т.3. (Июнь 1934 г. - март 1939 г.). М.: Наука, 1978. С. 525-526.

136 Безыменский Л. Гитлер и Сталин перед схваткой. М.: Вече, 2002. С. 169.

${ }^{137}$ Ibid. 
benefit from this decision, made in Munich, but we are not the last ones anyway. After us, the same fate awaits the others"138. Czechoslovak diplomat G. Masaryk concluded that "Czechoslovak

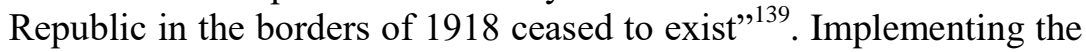
decisions of the Munich Conference, the Czechoslovak troops on October 1, 1938 "began to concede from the designated SudetoGerman line... The German army crossed the border of the Czechoslovak Republic at the same time. Germany annexed: October 1 and 2 - Volyary, Vyssy Brod, October 2 and 3 - Podmokly, Decin, Friedland, Velki Shanov, Shluknov, Rumburk, Vorisdorf, October 3, 4, 5 - Cheb, Karlovy Vary, Kadan, Yakilnov, Mariani Bani, Takhov, Niden, Falknov, Ash, Kraslice, Frantisek Lazne, October 6 and 7 Krnov, Bruntal, Frivaldov, Jawornin"140.

Since October 1, 1938 K. Henlein was appointed as the State Commissioner for the territories that left for Germany. On the same day, a note from the Polish Government of 30 September 1938 was considered at a session of the Czechoslovakian Government, which in an ultimate form called for the "retreat of the part of the Teschen region. Having considered Polish claims comprehensively, the Czechoslovak government could not have done otherwise than accept the Polish proposals in view of the difficult international position of Czechoslovakia, created by the Munich Treaty"141.

Although the issue of Subcarpathian Rus' was not considered in Munich, its decisions had a very negative impact on the fate of the region. On September 29, 1938 an "Addendum to the Agreement signed in Munich between Germany, the United Kingdom, France and Italy" was adopted, stating that "as soon as the question of Polish and Hungarian minorities in Czechoslovakia will be regulated, Germany and Italy will provide a guarantee to Czechoslovakia"142. It provided that "if within the next three months the problem of the

\footnotetext{
138 Документы и материалы кануна второй мировой войны. Т.1. Ноябрь 1937 декабрь 1938 г. Из архива Министерства Иностранных Дел Германии. М.: Политиздат, 1981. С. 318.

${ }^{139}$ Ibid. C. 314-315.

${ }^{140}$ Нова свобода. 1938. 4 жовтня.

${ }^{141}$ Ibid.

${ }^{142}$ Новые документы по истории Мюнхена. М.: Наука, 1958. С. 159. 
Polish and Hungarian national minorities in Czechoslovakia is not resolved between the governments concerned by the agreement, then this problem will be the subject of further discussion at the next meeting of the heads of governments of the four states, which are present here" ${ }^{\text {"143 }}$. The decision of the Munich Conference marked the first major victory of Hungarian diplomacy in the fight for the revision of the borders, which also directly concerned the fate of Transcarpathia $^{144}$. On October 1, 1938 Hungary's Regent M. Horthy wrote to Hitler that he was genuinely pleased that in Munich there had been "reached a peace agreement on crucial issues and that Hungary's legitimate elections would in principle be recognized as justified""145.

Hungarian diplomacy has done considerable work ahead of Munich. Head of the Chancellery of the Hungarian Ministry of Foreign Affairs I. Chaki, during a telephone conversation on September 15, 1938, instructed the Hungarian Ambassador to Germany, D. Stoyai: "If a discrimination towards Hungary will take place during the liquidation of the Czechoslovak case, then the Hungarian government will be ready for anything, and in this case, it counts on the support of the German Empire"146. On September 17, D. Stoyai, in a letter to the Minister of Foreign Affairs of Hungary, K. Kanya, forwarded H. Goering's proposals. According to him, Hungary must "officially demand the right for self-determination for the Hungarian minority in Czechoslovakia, it must appeal to the Czech government and other governments with a similar treatment to that of Henlein, it must provoke an armed clashes, strikes, refusal to appear at the recruiting points, because only serious incidents can draw attention of the Western states to Hungarian demands, it must do everything to make the foreign press be more involved in the Hungarian issue" "147. The Hungarian ambassador to Poland, A. Hori,

\footnotetext{
143 Ibid. C. 160.

144 Гранчак I.M., Гапоненко I.C. Закарпаття в міжнародних відносинах напередодні та в період Мюнхена. Нариси історії Закарпаття. Т. II. (19181945).Ужгород, 1995. С. 268.

145 Венгрия и вторая мировая война: Секретные дипломатические документы по истории кануна и периода войны. М.: Наука, 1962. С. 108.

${ }^{146}$ Ibid. C. 101.

${ }^{147}$ Ibid. C. 101-102.
} 
assured Warsaw that "Hungary, in case of the collapse of Czechoslovakia, claims the historical borders. My government considers this question to be resolved" $"$.

Poland has constantly defended Hungary's interests before Germany. "With about the Hungarian demands," wrote the Polish Ambassador to Germany J. Lipski, "I specifically highlighted the issue of Transcarpathian Rus', emphasized the strategic moment towards Russia (meaning the USSR - Aut.), the communist propaganda, which is carried out in this territory, etc. I got the impression that the Chancellor was very interested in this issue, especially when I told him that the length of the Polish-Romanian border was small and that thanks to the joint Polish-Hungarian border through Transcarpathian Rus' we would create a stronger barrier against Russia. In addition, I stated in relation to Transcarpathian Rus' that this territory, which Slovakia does not claim, was only given to Czechoslovakia as a mandate, that its population is on a very low level and is highly mixed, and that Hungary has the greatest interest in it" ${ }^{\prime 49}$.

On September 29, 1938 that is, just before the start of the Munich conference, B. Mussolini stated that "today will be a good day for Hungary. As soon as we are done with the question of the Sudeten Germans.., I will immediately put on the agenda the Hungarian and Polish claims, demanding their immediate satisfaction on the same basis as it will be done with regard to German claims" "150. "If they cannot be realized," said I. Chaki, "then he (Mussolini - Aut.) will insist on their implementation for a strictly defined period of time for a month. If this minimum program also does not work, then, he said, raising his voice, you will act... Put the world in front of the fact" ${ }^{\prime 151}$.

\footnotetext{
${ }^{148}$ Ibid. С. 26.

149 Документы и материалы кануна второй мировой войны. Т.1. Ноябрь 1937 декабрь 1938 г. Из архива Министерства Иностранных Дел Германии. М.: Политиздат, 1981. С. 211.

${ }^{150}$ Венгрия и вторая мировая война: Секретные дипломатические документы по истории кануна и периода войны. М.: Наука, 1962. С. 105.

151 Ibid.
} 
Therefore, Hungary was actively supported in its claims by Italy. This could not but affect Hitler, who in a conversation with British Prime Minister N. Chamberlain on September 22, 1938, stated that from Hungary at one time "a large territory was taken away, leaving against their will almost one million Hungarians in Czechoslovakia"152. On October 1, 1938 a representative of the USSR in Czechoslovakia, S. Alexandrovsky, informed the People's Commissariat of Foreign Affairs of the USSR that "in the Munich Agreement, Hitler signed a decision to give three months to regulate the issue of the Polish and Hungarian minorities and make it a subject of discussion by four states, if the Czech-Polish agreement would not be reached"153.

Following the decision of the Munich Conference, the Minister of Foreign Affairs of Czechoslovakia, K. Krofta, on October 1, 1938 addressed a Hungarian ambassador to Prague, J. Wetstein, with a note proposing "to establish as soon as possible a mixed CzechoslovakHungarian commission of experts in order to consider the problem of the Hungarian minority in Czechoslovakia. This commission should prepare and submit a draft resolution of that problem"154. On October 3, 1938 Hungary prepared the ultimatum requirements for the Czechoslovak government, which the latter had to accept: 1) to immediately release the political prisoners of Hungarian nationality; 2) to immediately demobilize and release home the soldiers of Hungarian nationality; 3) to create local units to protect the lives and property of the population. Squad Command mixed; 4) ...to transfer to Hungary 2-3 Czechoslovak border towns, which have to be occupied by Hungarian troops. In the West, such cities should be Komarno, or Parkanjana, or Upoishag, or Chop, or Beregovo; 5) ...the Hungarian government proposes to begin direct HungarianCzechoslovak negotiations in Komarno on Thursday, 6th day of this month, at 4 in the afternoon. I will personally lead the Hungarian

\footnotetext{
152 Документы и материалы кануна второй мировой войны. Т. 1. Ноябрь 1937 декабрь 1938 г. Из архива Министерства Иностранных Дел Германии. М.: Политиздат, 1981. С. 204.

153 Ibid. C. 243.

${ }^{154}$ Нова свобода. 1938. 5 жовтня.
} 
delegation (K. Kanya - Aut.) ${ }^{155}$. At the same time, A. Brodi, on October 6, 1938, was offered "in no case to obey the Czechs' promises" but to stand firmly in "a position of self-determination through plebiscite" $" 156$. The Prague project to solve the problem of national minorities was "to give the purely Hungarian ethnic territory to Hungary" and, as regards the plebiscite, it "is rejected as unrealistic and superfluous, because in the territories in which, according to the Hungarian authorities, a plebiscite should be held, there is no longer a Hungarian majority" ${ }^{\prime 157}$. There even could be no talk of a plebiscite in Uzhgorod, Mukachevo and Sevlyush (Vynohradiv).

Such positions were held by government delegations of Czechoslovakia and Hungary on the eve of the Komarno conference, which took place $9-13$ October, 1938. Hungarian diplomacy, with the support of the fascist states led by Germany, put forward difficult conditions for Czechoslovakia: to return the lands, inhabited by the Hungarians, (on the base of the 1910 census, when the number of Hungarians was greatly exaggerated), to hold a plebiscite in the territories with mixed population, to grant the right of selfdetermination to all other peoples ${ }^{158}$. "In case of fulfilment of these Hungarian claims," "Nova Svoboda" reported, "Hungary would have taken... 400 thousand Slovaks and 80 thousand Ukrainians, so the Slovak-Ukrainian minority in the Hungary would be larger than the Hungarian minority in Czechoslovakia"159.

The negotiations in Komarno did not give any positive results. They were thwarted by the fault of Hungary. Czechoslovakia could not accept the Hungarian requirements, because during the 1910 census, "the commissioners of the Hungarian authorities

\footnotetext{
${ }^{155}$ Венгрия и вторая мировая война: Секретные дипломатические документы по истории кануна и периода войны. М.: Наука, 1962. С. 11.

156 Ibid. C. 112; A Magyar Tudomanyos Akademia Tortenettudomanyi Intezete. Magyarorszag es a Masodik Vilaghaboru. Titkos Diplomaciai Okmanyok a Haboru Elozmenyeihez es Tortenetehez. Masodik kiadas. Budapest: Kossuth Kцnyv kiado, 1961. C. 144-145.

${ }^{157}$ Нова свобода. 1938. 28 жовтня.

158 Гранчак I.M., Гапоненко I.C. Закарпаття в міжнародних відносинах напередодні та в період Мюнхена. Нариси історії Закарпаття. Т. II. (19181945). Ужгород, 1995. С. 269.

159 Нова свобода. 1938. 16 жовтня.
} 
included in the rubric of the Hungarian nationality everyone, who could speak Hungarian, and also included the religion"160. On October 14, 1938 representatives of the Hungarian delegation formally declared that Hungary was "interrupting the negotiations, because it cannot continue them due to Czechoslovak preconditions" $"$. After the collapse of the negotiations in Komarno, a new stage has emerged in solving the "Czechoslovak problem". Hungary, accusing Czechoslovakia of reluctance to make concessions, appealed to Italy and Germany to arbitrate the situation. Great Britain and France have declared their disinterest in this issue. B. Mussolini advised the Hungarians "to demand an urgent call for an immediate convening of a conference of the four great states, stating that there is little hope of resuming direct bilateral negotiations, and stressing that delay in resolving the issue will pose a threat to peace"162. To this Mussolini added that "at the first request, the planes (Italian - Aut.) will be immediately deployed to Hungary. They are in full readiness, and they need an hour and a half to get to Budapest" ${ }^{\prime 63}$. In a conversation with the new Minister of Foreign Affairs of the Czechoslovak Republic, F. Khvalkovsky, Hitler "expressed his pity that the issue of the Hungarian minority in Czechoslovakia had not yet been resolved"164. In a conversation with the Ambassador of Hungary to Berlin, D. Stoyai, H. Goering tried to reassure the Hungarians and "expressed confidence that Hungary would return its territories without war" ${ }^{\prime 65}$. The session of the arbitration commission was appointed on November 2, 1938.

On the eve of the arbitration, Hungary had high expectations on its agent A. Brodi, who, under the leadership of the government of Subcarpathian Rus', had to invite the Hungarian troops to occupy all of Transcarpathia. The Polish government held a similar view. According to Hungarian Ambassador to Poland A. Hori, "one of the

\footnotetext{
160 Нова свобода. 1938. 29 жовтня.

161 Нова свобода. 1938. 15 жовтня.

162 Венгрия и вторая мировая война: Секретные дипломатические документы по истории кануна и периода войны. М.: Наука, 1962. С. 114.

163 Ibid. C. 115.

164 Нова свобода. 1938. 16 жовтня.

165 Венгрия и вторая мировая война: Секретные дипломатические документы по истории кануна и периода войны. М.: Наука, 1962. С. 115.
} 
formulas... could be a statement that the Ruthenian population has asked both Hungarian and Polish troops to enter the Ruthenian region. Such an action could be quickly prepared or organized. You can also choose the following decision: Hungarian troops that will enter the Ruthenian region will seek support from the Polish army. Of course, this needs to be agreed earlier"166. However, Czechoslovak counterintelligence has closely followed the prime minister's every move. On October 27, 1938 A. Brodi was arrested, and A. Voloshyn, who headed the new cabinet, clearly adhered to the anti-Hungarian orientation. The new appointment by Prague convinced Hungary that no territorial concessions could be expected from A. Voloshyn, and the transfer of all Transcarpathia couldn't be even mentioned. A. Voloshyn arrived in Vienna on November 2, 1938, but did not participate in the work of the arbitration commission. We have to agree with V. Grendzha-Donsky that the Transcarpathian delegation "was invited not for consultations, but for getting a ready decision" $" 167$.

The text of the first Vienna Arbitration Award of November 2, 1938, signed by the Ministers of Foreign Affairs of Germany and Italy, provided: "1. Areas departing from Czechoslovakia to Hungary are indicated on the attached map. The Hungarian-Czechoslovak commission must set the border. 2. The evacuation of the outlying regions of Czechoslovakia and their transfer begins on November 5, 1938 and must be completed by November 10, 1938. Separate stages of evacuation and transfer, as well as other formalities, should be determined immediately by the Hungarian-Czechoslovak commission. 3. The Czechoslovak Government should ensure that evacuated areas are transferred in full. 4. Separate issues arising from the territorial retreat, especially issues of citizenship and optation, must be resolved by the Hungarian-Czechoslovak commission. 5. The Hungarian-Czechoslovak Commission must also take more specific decisions on the protection of both persons of Hungarian nationality who remain in the territory of Czechoslovakia and persons of non-

\footnotetext{
${ }^{166}$ Ibid. C. 133.

167 Гренджа-Донський В. Щастя і горе Карпатської України: Щоденник. Мої спогади / Ред. Д.М. Федака. Ужгород: ВАТ «Видавництво «Закарпаття», 2002. C. 163 .
} 
Hungarian origin in the retreating regions... 6. As the transfer to Hungary could be detrimental and economic and communicational difficulties would arise in the regions under Czechoslovakia, the Hungarian royal government, in its agreement with the Czechoslovak government, would do its utmost to remedy such difficulties" ${ }^{\text {"168. If }}$ the Hungarian-Czechoslovak commission fails to resolve the controversial issues, then they will be discussed by Germany and Italy.

According to the decision of the arbitration commission, the new Hungarian-Czechoslovak border was passing along the settlements of Bovtrad, Mali and Velyki Hut, Janoszowo, Kwasowo, Orosievo, Kerestury, Vilok, Beregovo, Yovrya, Uzhgorod, Radvanka, Dravtsi, Velyki Heevtsi, Kholmets, Velyka Dobronj, Barkasovo, Zhniatyno, Kliucharky, Mukachevo, Fornosh, Nove Selo, Vyshni Remety, Shalanky, Matievo, Choma, Chorny Ardiv ${ }^{169}$. According to the information in "Nova Svoboda", which was based on the official statistics, "the territory of the Czech Republic decreased by 33\%, Moravia by $36 \%$, Slovakia by $21 \%$, and the territorial losses of Subcarpathia... amounted to $12 \% " 170$. Czechoslovak Republic "retreated 28.200 sq. km. to Germany, about one thousand sq. km. to Poland, about 12.000 sq. km to Hungary. The current republic will have about 100.000 sq. km."171. Hungary took 171.711 people, of which 33.324 were Ukrainians, 16.463 were Czechs and Slovaks, 82.179 were Hungarians ${ }^{172}$.

The Vienna arbitration has affected five Transcarpathian districts - Uzhgorod, Mukachevo, Beregovo, Sevliush and Irshava. Subcarpathian Rus' lost the cities of Uzhgorod, Mukachevo, and Beregovo with the surrounding areas. In Uzhgorod district Hungary took 22 settlements, in which 10.719 Ukrainians and 18.687 Hungarians lived, in Mukachevo - 15 settlements (12.153 Ukrainians

\footnotetext{
${ }^{168}$ Венгрия и вторая мировая война: Секретные дипломатические документы по истории кануна и периода войны. М.: Наука, 1962. С. 120.

${ }^{169}$ Нова свобода. 1938. 11 листопада.

${ }^{170}$ Нова свобода. 1938. 15 листопада.

${ }^{171}$ Нова свобода. 1938. 8 листопада.

172 Шандор В. Спомини. Т. 1. Карпатська Україна. 1938-1939. Ужгород: МПП «Гражда»; Карпатський Союз, 1996. С. 262.
} 
and 12.253 Hungarians), in Sevliush - 18 villages (3.471 Ukrainians and 8.752 Hungarians), in Beregovo district - 40 settlements (6.343 Ukrainians and 40.962 Hungarians), in Irshava - the only settlement the village Shalanky, in which 648 Ukrainians and 1525 Hungarians lived $^{173}$. It is necessary to agree with P. Stercho's assertion that "Ciano and Ribbentrop, by their decision of November 2, 1938 in Vienna, violated ethnographic principles, because they gave two cities to the Hungarians, that is, Uzhgorod and Mukachevo with a relative majority of the Ukrainian population, as well as 13 villages with an absolute majority of the Ukrainian population, among which in 4 villages the Hungarians did not make up one percent of the population. In addition, four villages with a relative majority of the Ukrainian population were given to Hungary" ${ }^{174}$. In Baranyntsi, for example, there were $77 \%$ of Ukrainians, in Yovra $-62 \%$, in Dravtsi - 93\%, in Korytnyany - 72\%, in Kvasovo $85 \%$, in Vyshny Remety - 92\%, in Nyzhny Remety - 93\%, in Chepa $67 \%$.

According to the decisions of the Vienna Arbitration, a joint Czechoslovak-Hungarian demilitation commission was set up, with 11 subcommittees in its structure. They solved the general political, military, territorial, ethnographic, financial, national economic, trade, legal problems. Two Ukrainians, two Slovaks and one Czech were delegated to the joint Czechoslovak-Hungarian commission $^{175}$. Carpathian Ukraine was represented by Y. Brashchayko and M. Dolynai. The functions of experts were performed by J. Jirkovsky, L. Makhachek and V. Primich. The representatives of Carpathian Ukraine and Hungary reached an agreement on a permeable system, export of property from the territory occupied by Hungary. "Nova Svoboda" reported: "Movable property will be exportable within two months since the railway and communication movement between the two countries will be started"176. The communication line had to start its work on January 9, 1939. The

\footnotetext{
${ }^{173}$ Ibid. C. 74-75.

174 Стерчо П. Карпато-Українська держава: 3 історії визвольної боротьби карпатських українців у 1919-1939 роках. Торонто, 1965. С. 76.

${ }^{175}$ Нова свобода. 1938. 21 грудня.

${ }^{176}$ Нова свобода. 1938. 24 грудня.
} 
evacuation, which ended on November 10, 1938, was headed by V. Komarynsky, D. Nimchuk and V. Grendzha-Donsky ${ }^{177}$.

In the circular of the Presidium of the Regional Administration of Subcarpathian Rus' in Uzhgorod, there was an order of evacuation of Czechoslovak authorities from the territory that was taken by Hungary, following the results of the Vienna Arbitration ${ }^{178}$. The Vienna arbitration struck a significant blow to Czechoslovakia and Carpathian Ukraine, though Hungary had not yet achieved full occupation of the region. It resulted in the creation of a new Hungarian-Czechoslovak border. Carpathian Ukraine continued to be part of Czechoslovakia, making the formation of a common border between Hungary and Poland impossible $^{179}$. Czechoslovak President E. Gacha also called on Czechs, Slovaks and Ukrainians to "work hand in hand to rebuild the state" " The authorities of Carpathian Ukraine were forced to agree with the decision of the arbitration commission. The Manifesto "Ukrainian People of Subcarpathia!", adopted by the Ukrainian Central People's Council on November 17, 1938, stated: "With a pain in the heart, we inform You that, at the request of Hungary, two great states, which created an arbitration commission to solve a dispute over the borders of our young Subcarpathian state, gave a large chunk of our ancient land together with the cities of Uzhgorod, Mukachevo and Berehove to Hungary. Relying on the false statistics of our enemies, they detached from the living body of the Ukrainian people many villages and cities, where the overwhelming majority of Ukrainians-Ruthenians lives... Our representatives at the Vienna International Conference were forced to accept the terms of the arbitration comission" ${ }^{\prime 181}$.

${ }^{177}$ Гренджа-Донський В. Спогади. Листи . Твори. Т.Х. Вашингтон, 1988. С. 165.

178 Карпатська Україна. Документи і матеріали. Хроніка подій. Персоналії: У двох томах. Том 1. Карпатська Україна. Документи i матеріали / Упорядники - О. Д. Довганич, О. М. Корсун, О. М. Пагіря; редакційна колегія: М. А. Попович (голова), О. Д. Довганич (заст. голови), М. М. Вегеш, М. В. Делеган, В.К. Дрогальчук, О. М. Корсун, І. Ю. Коршинський, О. Ю. Кучерява, О. М. Пагіря, С. Д. Федака; редактор Д. М. Федака. Ужгород: ВАТ «Видавництво «Закарпаття», 2009. С. 92.

${ }^{179}$ Нова свобода. 1938. 7 грудня.

${ }^{180}$ Нова свобода. 1938. 27 грудня.

${ }^{181}$ Нова свобода. 1938. 17 листопада. 
The Vienna arbitration testified to the deepening political crisis in Czechoslovakia, which in fact faced a state disaster. The further development of political events in Europe was crucially dependent on Germany. This was well understood by all the leaders of the European countries. The government of Carpathian Ukraine was aware of this, too. From the very first days of his premiership, A. Voloshyn began to focus on Germany, the only major country that promised him its patronage. The German government, playing with the cabinet of A. Voloshyn, announced the opening of its consulate in Khust. This was done in order to keep under control the development of the political events in the region. A. Voloshyn hoped that the appointment of $\mathrm{H}$. Hoffman as a consul "is not a journey of curiosity, but is a route of study that will have its specific consequences for our land, for our people and for the further policy of Germany towards us" ${ }^{\text {"182 }}$.

It should be noted that the German government delayed the opening of its consulate in Carpathian Ukraine several times. In particular, on November 19, 1938, the Minister of Foreign Affairs of Germany, J. Ribbentrop, informed the adviser of this ministry, E. Wermann: "According to the Führer's order and before a new order, the Slovak and Carpatho-Ukrainian issues must be treated frostily. For this reason, the press was instructed not to publish anything about the events in Carpathian Ukraine. In addition, the question of establishing a general consulate in Khust is being postponed"183. The adviser to the German Embassy in Poland, R. Sheliga, stated that "Poland's fears that Germany intends to give a start to the All-Ukrainian state from Subcarpathian Rus' have no reason. Germany has already issued instructions not to create such an impression. Subcarpathian Rus' will retain its independence within Czechoslovakia and will play no role in international politics"184. Anyway, the government of Nazi Germany opened a consulate in Khust. Transcarpathians were allowed to go to work in Germany, which, to some extent, reduced unemployment. The government of A. Voloshyn became so enthusiastic about this proposal that on March 6, 1939, just 8 days before the occupation of the region by the Hungarian troops, it was

\footnotetext{
182 ДАЗО. Ф. 3. Оп. 1. Спр. 45. Арк. 1.

183 Косик В. Україна і Німеччина у другій світовій війні. Париж - Нью-Йорк Львів, 1993. С. 459.

184 Ibid. C. 472.
} 
resolving the issue of producing 10 thousand passports ${ }^{185}$. Believing naively in Hitler's promises of help, A. Voloshyn asked H. Hoffmann to "convey... to the glorious leader of the German people... our sincere thanks and heartfelt greetings" $" 186$.

From the above, we can conclude that the government of Carpathian Ukraine clearly adhered to the pro-German orientation, while pursuing the sole aim: to preserve the territorial integrity of the region, to protect its population from the aggression of the fascist Hungary. This statement is proved by the materials of the "Personal Case of A. Voloshyn", which is contained in the Central Archives of the Ministry of State Security of Russia in Moscow. In answering the questions of MGB Investigator Major Weindorf, A. Voloshyn stated unequivocally that "the government of Subcarpathian Rus' set the task of creating an autonomous Transcarpathian Ukraine and focused on Nazi Germany, that is, in the latter we saw the power that could ensure the inviolability of the territory of Carpathian Ukraine. I would like to point out that the position of Germany, as the state of arbitration at that time, forced the government of Subcarpathian Rus' to ask Germany for border protection against the occupation of the land by the Hungarians"

It is known that part of the German generals advised Hitler to maintain the independence of Carpathian Ukraine. Advisor to the Ministry of Foreign Affairs of Germany E. Kleist confessed that he "tried all the time to protect Transcarpathian Ukraine"188. In 1937 W. Canaris met the Chairman of the Leadership of the Ukrainian Nationalists E. Konovalets. The admiral promised to help him in subversion and propaganda. Canaris remembered Colonel Konovalets, and when he was killed in 1938 in a terrorist act organized by the Soviet special services, Canaris kept reminding "this wonderful man"189. Ukrainian nationalist emigration, in particular, supporters of I. PoltavetsOstryanytsya and Hetman of Ukraine (in exile) P. Skoropadskyi, played

\footnotetext{
185 ДАЗО. Ф. 17. Оп. 2. Спр. 383. Арк. 19.

186 ДАЗО. Ф. 3. Оп. 1. Спр. 45. Арк. 2.

187 Центральный архив Министерства государственной безопасности РФ. Н-17681. Л. 10.

188 Косик В. Україна і Німеччина у другій світовій війні. Париж - Нью-Йорк Львів, 1993. С. 471.

189 Волков А., Славин С. Адмирал Канарис - «железный» адмирал. Москва Смоленск: «Олимп»-«Русич», 1999. С. 314.
} 
a role in the pursuit of the pro-German policy by A. Voloshyn ${ }^{190}$. As for this organization, in the late 1930s it was transformed into a small national-socialist group, fully embracing fascist ideology and practice ${ }^{191}$. The leadership of the OUN also played a role in the rapprochement of A. Voloshyn's government with Germany. This organization saw in Germany the savior of Galicia from Polish oppression. It was at their request that German military advisers, who contributed to the formation of local armed forces, appeared in the region. There is no doubt that there was a close relationship between the OUN and the German special services.

Thus, in the late 1930s, the international situation escalated sharply in Central Europe, and the Second World War was approaching. The Munich Conference of September 29-30, 1938 struck a significant blow to Czechoslovakia. It, like the Vienna Arbitration on November 2, 1938, in fact, signaled the beginning of the state breakup of the Czechoslovak Republic and was a prelude to the full occupation of the country by Germany and Hungary in March 1939. These decisions were the first significant success of Hungarian diplomacy on the way of implementation of its revisionist foreign policy. The collapse of the Czechoslovak Republic was possible because of a policy of toleration of aggression promoted by Britain and France. The neutral position was occupied by the United States. The USSR's attempt to help Czechoslovakia was unsuccessful.

Germany's policy towards Carpathian Ukraine has undergone some evolution. Initially, it did not agree to the full occupation of Transcarpathia by Hungary, fearing the establishment of a joint PolishHungarian border. Only after it was convinced that Hungary intends to withdraw from the League of Nations and join the Anti-Comintern Pact, Berlin agreed to the elimination of Carpathian Ukraine. The governments of Romania and Yugoslavia have been loyal to Czechoslovakia's policies. Romania made its territorial claim to the Czechoslovak Republic only when Hungary invaded the territory of Transcarpathia and the fate of the federation was resolved.

190 ДАЗО. Ф. 3. Оп. 1. Спр. 42. Арк. 1.

${ }^{191}$ На переломі. 1939. Ч. 5. 